\title{
Alice in Wonderland: Unrealized fertility and satisfaction with number of children according to couples' point of view in a city in Brazil
}

\author{
Angelita Alves de Carvalho* \\ Laura Rodriguez Wong ${ }^{\star *}$ \\ Paula Miranda-Ribeiro ${ }^{\star \star \star}$
}

The gap between ideal and observed fertility is a very common phenomenon in Brazil. However, given the severe criticism of indicators on desired and ideal family sizes, it is important to reflect on how well fertility preferences are grasped by traditional questions. This paper discusses whether having fewer children than desired is a matter of choice or if it represents an inability to implement reproductive preferences, generating dissatisfaction with one's fertility behavior. Data come from 62 in-depth interviews conducted with 31 couples with high educational levels, living in Belo Horizonte, Brazil, with up to two children. Negative discrepant fertility was predominant among most couples interviewed. Many of them, however, are fully satisfied with their current fertility situation and do not seem to be willing to implement their desire for more children.

Keywords: Fertility gap. Ideal number of children. Negative discrepant fertility. Measures of fertility preferences. Qualitative data. Couples.

\footnotetext{
* Escola Nacional de Ciências Estatísticas (Ence), Instituto Brasileiro de Geografia e Estatística (IBGE), Rio de Janeiro-RJ, Brazil (litaacarvalho@yahoo.com.br; http://orcid.org/0000-0002-9342-4181).

${ }^{\star \star}$ Centro de Desenvolvimento e Planejamento Regional (Cedeplar), Universidade Federal de Minas Gerais (UFMG), Belo Horizonte-MG, Brazil (lwong@cedeplar.ufmg.br; http://orcid.org/0000-0002-4041-1985).

${ }^{* * *}$ Centro de Desenvolvimento e Planejamento Regional (Cedeplar), Universidade Federal de Minas Gerais (UFMG), Belo Horizonte-MG, Brazil (paula@cedeplar.ufmg.br; http://orcid.org/ 0000-0002-6702-0175).
} 


\section{Introduction}

Below replacement fertility is a reality in several Latin American countries and is practically widespread in the large urban agglomerations of the continent. Cities such as Bogotá, São Paulo, and Lima already had a TFR (Total Fertility Rate) below 2.1 by 2010. Meanwhile, the proportion of women wishing to have more children than they actually do is increasing in Latin American context (WONG, 2009), as in developed countries (SOBOTKA; BEAUJOUAN, 2014). Brazil is included in this pattern, as while the ideal number of children was 2.1 in 2006, the observed TFR was 1.8 (BERQUÓ; LIMA, 2008). There is a significant proportion of couples with fewer children than they desire, who would probably be unable to implement their reproductive preferences.

With a downward trend in fertility for the coming decades in Brazil (IBGE, 2013), it is important to consider not only women's but couples' reproductive preferences and the leading motivations of the latter to implement their fertility intentions (MORGAN; TAYLOR, 2006). Studies on reproductive preferences represent a relevant contribution to the literature, particularly where fertility is below replacement level and there is probably a discrepancy between the number of wanted children and those effectively born, with possible unmet demand due to lack of children (PHILIPOV et al., 2009). The inability to have the ideal number of children is often attributed to individuals' unfavorable personal circumstances, which may interfere in their early intentions to procreate or change their intentions throughout life (BACHRACH; MORGAN, 2013).

The term fertility gap was described by Chesnais (1999) as the large difference between the observed fertility rate and the desired number of children. Many studies have focus on research regarding the issue, especially after finding that the number of desired children in developed societies does not decline at the same proportion as fertility does. These studies point out that this gap reflects the existence of unrealized fertility and suggest a window of opportunities for policy action, known as "latent" demand for policies, designed to support individuals and couples wishing to have their desired number of children (GOLDSTEIN et al., 2003; PHILIPOV, 2009; SOBOTKA; BEAUJOUAN, 2014). In this case, the decision of having less children than desired is a strong argument in favor of social policies aimed at removing obstacles such as economic and sociocultural contexts, specially unstable working conditions, gender inequalities, or difficulties in combining family and work (OECD, 2007). Although Pardo and Varela (2013) do not estimate the fertility gap directly, they discuss low fertility levels in some Latin American countries and the increase in the existence of unrealized fertility, highlighting the need to think about public policies to ensure couples have the desired number of children.

Studies about the fertility gap outside developed countries are still rare (CASTERLINE; HAN, 2017). In Latin America, the norm of two desired children prevails and has been often accompanied by below replacement fertility in many countries. In Nicaragua, the percentage of women reaching the end of their reproductive lives with fewer children than their ideal family size was $24.2 \%$ in 1998 , whereas in the Dominican Republic, this figure was $41.1 \%$ 
in 1996 (HAKKERT, 2003). Similar evidence was found for Mexico (CHACKIEL; SCHKOLNIK, 2003). In Uruguay, the negative discrepancy is present in almost all socioeconomic strata, with one in three women finishing the reproductive period with fewer children than desired. Only women in the higher socioeconomic strata and, among them, those who had two or three children do not have a negative discrepancy (PERI; PARDO, 2008). In Haiti, Colombia, and the Dominican Republic, women of different social classes, not just the more privileged ones, also have lower fertility than their ideal number of children (WONG, 2009). In Brazil, this percentage reaches almost $34 \%$ among married women $45-49$ years old and becomes even higher among those with higher schooling (50\%) (CARVALHO et al., 2016).

Despite the increasing trend in the percentage of women with fewer children than the declared ideal in Brazil, there are few studies that delve deeper into this issue (GONZALEZ, 2015; CARVALHO et al., 2016). Much of the literature still focuses on unwanted fertility. Among couples who have more children than they desire, the availability of and access to contraceptive services usually result in narrowing the gap between realized and desired fertility. However, it is less explicit what mechanisms would work on couples who have fewer children than they claim to want.

There is severe criticism of indicators that measure desired and ideal family size, which restrain the potential of data on reproductive preferences to adequately reflect the intentions and satisfaction with fertility behavior (IACOVOU; TAVARES, 2011). Thus, the central question refers to the reliability of cross-sectional data to explain whether having fewer children than desired really leads to dissatisfaction with fertility behavior in Brazil. Are couples enabled to implement their reproductive preference or do they fail in this process and if so, why? Does the two children ideal family size remain in force, or has fertility behavior changed because couples have chosen fewer children due to other interests? Irrespective of the answer, advances in these discussions are necessary.

The aim of this study is to analyze the number of desired children and those actually born and currently living. These elements will allow us to elucidate the relationship between negative fertility discrepancy and satisfaction with actual fertility. We will also discuss the inability to implement reproductive preferences and their facilitators and constraints.

Data come from 62 in-depth interviews with 31 couples of high educational level, among which this phenomenon has been more frequently found (BERRINGTON; PATTARO, 2014; CARVALHO, et al., 2016). In addition, this study shows the potential of qualitative data in research on implementation of reproductive preferences and fertility behavior by introducing a new look into the comprehension of the discrepancy and satisfaction phenomenon with fertility.

\section{Negative discrepant fertility and its estimation limitations}

Desires and intentions for childbirth are the most subjective dimensions of fertility and they have been used to improve the accuracy of fertility predictions and evaluate the fertility 
achieved. It is important to consider the differences in meaning of different indicators. Although there is no full consensus, literature on the topic shows some definitions of the main indicators and terms in the fertility preferences review. This does not mean pointing to a single path of how to measure these indicators.

According with Thomson (1997), the desire for children reflects the will to reach an objective by some type of action, thought in an unrestricted way, and, consequently, fertility preferences are feelings or desires related to having children. Fertility intentions involve a specific decision to pursue a goal, associated to a commitment and a plan to implement that decision. That is, intentions are subdued to situational constraints that act on doing what one wants, incorporating factors such as the individual's personal circumstances and perceptions of the desires of their partners. Lastly, fertility expectations are realistic projections of future fertility that incorporate desires for children, beliefs about fecundity, and access to contraception (RYDER; WESTOFF, 1967; MILLER; PASTA, 1995; THOMSON, 1997).

Since the 1950s, many studies have shown that measures of reproductive intentions have a high level of accuracy for determining fertility rates (MORGAN, 1985; WESTOFF; RYDER, 1977; WESTOFF, 1990; BONGAARTS, 1992). Furthermore, fertility intentions predict fertility behavior better than other factors, including parity, birth interval, education, employment status, and religion (LIEFBROER, 2009; MORGAN; RACKIN, 2010). Fertility preferences have been used for a long time to determine the demand for children in a population, while assessing the extent to which the outcomes of this decision-making process for children are satisfactory for individuals (MCCLELLAND, 1983; CASTERLINE; EL-ZEINI, 2007).

However, since the increase of negative discrepant fertility, the strength of fertility prediction from desires and intentions has been low. On the one hand, this is due to lack of information about the reasons why people are not performing their desired fertility and, at the same time, to the difficulty of finding panel data series, through which it is possible to follow change in desires and their enablers and constraints (PHILLIPOV, 2011).

In most low fertility countries, people report that they would like to have two or three children whilst fertility remains below replacement level, which points out an inefficiency in achieving the desired fertility. The preference for two children is common in both developed and developing countries because of different forces. On the one hand, upward pressure refers the concerns of having only one child; on the other, downward pressure refers to the perception that having four or even three children means a large family. This pattern becomes more consistent and internalized throughout the course of life, which increases the convergence of fertility intentions to the social norm of two children (MORGAN; RACKIN, 2010).

There has been an increase in the difference between desired and achieved fertility in recent decades with the decline of fertility to below replacement levels not following, in most countries, falls in fertility intentions (BONGAARTS, 2001; 2002). Conversely, there are also countries where national average of desired children has fallen below replacement levels; this may result, in view of the high cost of children and the trend towards consumerism and 
individualism, in the desired family size to fall further in the coming decades (GOLDSTEIN et al., 2003; BONGAARTS, 2011).

This growing gap is the result of biological, economic and social constraints to having children (PHILIPOV et al., 2009; LIEFBROER, 2009). The changes in fertility time due to postponement of motherhood to more advanced ages and competition with other activities in modern society, where couples have simultaneous preferences and priorities, has been pointed out as one of the main determinants of this discrepancy. As couples are generally unable to fulfill all of these desires at the same time (some being mutually exclusive), individuals end their reproductive period with fewer children than those declared in surveys as the ideal number they would like to have (DEMENY, 1997). Moreover, there are several mechanisms that influence the lack of fulfillment of the desire for higher fertility, including educational level, employment stability, career and leisure preference (HAKIM, 2003; ADSERA, 2006; MORGAN; RACKIN, 2010; BELLANI; ESPING-ANDERSEN, 2013) lack of partner, satisfaction and relationship stability (RIJKEN; LIEFBROER, 2009; CREIGHTON et al., 2013), gender contexts that reflect on the difficulty of reconciling work and childcare (MCDONALD, 2000; ARPINO et al., 2015), disagreement between partners' desires (MILLER; PASTA, 1995; IACOVOU; TAVARES, 2011), and health issues, among others.

In addition to these factors that may lead to the non-fulfillment of desires and intentions for children, there is serious criticism about the information traditionally gathered on this issue, which influences the prediction of fertility. The most widely used measure to evaluate reproductive preferences is the desired number of children, usually gathered from the question about the number of ideal family size or ideal number of children. However, preferences can be measured in other ways, such as the couple's intention for children; whether the birth of the last child was desired; whether another child is desired; what the total number of children desired is; and, if it were possible to have exactly the number of children desired, what this number would be (WESTOFF; RYDER, 1977). Moreover, Morgan (1981) already alerted to a characteristic inherent to the intentions of fertility which is uncertainty. He claimed that ignoring this uncertainty conceals much of what could be learned from data on fertility intentions.

Uncertainty and ambivalence were studied by Santelli et al. (2009) who showed that intending to become pregnant may be distinct from the desire to be pregnant, that is, the concept of planning a pregnancy may not be meaningful for some women; there may be an ambivalence about avoiding pregnancy and this can be expressed in the imperfect use of contraception. This ambivalence between desires and attitudes to implement pregnancies or not were also studied of Miller et al. $(2013,2016)$ who showed that the existence of ambivalence, defined as an interaction between positive and negative pregnancy desires. They found that positive and negative pregnancy desires independently predict the risk of an unplanned pregnancy. They affirm the importance to consider the desire of having or not having children separately, but the interaction and ambivalence of these situations over the time in which reproductive decisions are being made. The combination of desires 
for positive and negative children (low, high and null) are better predictors of fertility than their individual analysis (MILLER et al., 2013, 2016).

Another difficulty in the study of fertility preference is the limitation of data, which should be a panel (PHILLIPOV, 2011). In order to study preferences for children, it should be ackonwledged that they do not consolidate early in reproductive life and are an essentially static goal to be achieved throughout the rest of life. Fertility must be thought of as a dynamic process, in which intentions are shaped and revised in the lapse of vital processes and experiences. Moreover, it may be that people come, through a sequence of stages, into a family size they "discover" to be good for them, and sometimes they will only find out when they reach it. That is, the ideal number of family can be a discovery rather than a goal. This does not imply that this number is always a perfect result between preferences and behavior. People may discover, too late, that they would have preferred fewer or more children than they eventually have (IACOVOU; TAVARES, 2011; NÍ BHROLCHÁIN; BEAUJOUAN, 2015).

Other variables, related to the most different aspects of life experiences, also have a strong relation with fertility preferences. Young people have vague and unclear preferences, which become more concrete with age, and usually tend to be reduced with the advancement of the reproductive period. Marital status can lead to changes in reproductive plans, as people consider their partner's fertility plans and revise their own plans, as well as beginning of new relationships increase intentions for children. Finally, changes in intentions for children are related to one's own experience of motherhood and parenthood, for there is an upward or downward adjustment of intentions for children depending on how positive or negative the experiences with children are perceived (IACOVOU; TAVARES, 2011). Thus, individuals are better able to provide a more realistic assessment of the situation of their preferences for children in a shorter period. This reduces the possibility of unforeseen events which may change reproductive plans (KUHNT; TRAPPE 2013).

Along the same lines, Yeatman et al. (2013) showed, for a context of transitioning fertility, that family size preferences are not fixed, but flexible. Women, even young women early in their reproductive careers, altered their ideal family size reports over time and in response to life circumstances, including relationship changes and undoubtedly other factors - such as economic conditions. The authors argued family size preferences are not perfect guides for reproductive behavior, because "they represent a moving target that takes into account internalized societal norms, relationship context, reproductive experiences, and individual hopes" (YEATMAN et al., 2013, p. 1734). Finally, they draw attention to the fact of that many researchers say that preferences do not adequately predict future family size. However, family size preferences reflect the conditions an individual is experiencing at one particular point in time: namely, the time of the survey.

Another important point is that information about preferences mostly focuses on women's reports, which, depending on context, may have little influence in making decisions about their fertility behavior (CALDWELL et al., 1985). There is also a problem caused by the rationalization effect, which occurs when people adjust their desires in relation to the 
number of children they already have (BONGAARTS, 1992). This rationalization can take place on two levels, inflating the response for children desires due to the person's having more children than desired and, on the other hand, reducing the ideal number of children declared, given that they have not reached the desired family size (HAKKERT, 2003).

Moreover, these measures may be volatile and inaccurate with regard to individual fertility behavior, since instead of reflecting the respondents' personal preferences, they may reflect local, social norms. Thus, it would be better to use the term 'personal ideal' number of children, since this question is expected to be less influenced by social norms. Nevertheless, this individualized ideal probably does not incorporate the ideal conditions of life that people imagine when effecting this mental construction, as there is certain unrealism and / or imagination in this measure (GOLDSTEIN et al., 2003). Another problem that may also occur is that the term "ideal family size" does not include the option of not having children in the minds of many respondents, keeping them from revealing the option for zero. This would make the fertility gap greater than it really is (SOBOTKA; BEAUJOUAN, 2014).

Finally, the desired fertility indicators are general and imprecise because the ideal number of children is usually interpreted as the number of children an individual would like to have under ideal conditions of life. However, "ideal" conditions of life can hardly be satisfied, i.e. as an indicator to measure the extent of policy needs, the ideal number of children can be seen as biased upwards, so they do not provide realistic and timely information on the obstacles that have prevented their fulfillment. In the vast majority of cases, respondents will only know if they will actually have the number of children predicted decades after their intentions have been measured. In addition, information about obstacles to becoming pregnant becomes available only when it is too late for a policy intervention. That is, indicators available on desired fertility seldom realistically reflect expectations about having a child. Therefore, they do not provide correct information about barriers to procreation and identification of those that can be addressed through relevant public policies (PHILIPOV et al., 2009).

All this makes the measurement of reproductive preferences and the evaluation of its implications for the satisfaction of people fertility behavior quite complex. However, as was previously demonstrated, these are the most commonly used indicators to predict and think about fertility trends.

\section{Methodology}

This is a qualitative study, characterized by a case study. According to Yin (1994), it is suitable to understand, explore or describe events and complex contexts, it is possible to identify the "how" and "why?" of the dynamics of a phenomenon, which seeks a deepening on topics of interest. This type of study was chosen due to the complexity of the process 
that involves understanding the implementation of reproductive preferences and the discrepancy between fertility desires and realized.

Data come from fieldwork carried out from June to August 2013 in Belo Horizonte, Brazil. We interviewed 31 couples, which generated a total of 62 interviews, conducted individually with each partner. Couples were married or had been cohabiting for at least 1 year, wives were 35-44 years-old, had attained higher education level or higher and had 0-2 children. Before the interview began, each interviewee responded a mini survey, with questions identical to those used in the Demographic and Healthy Surveys (DHS) ${ }^{1}$ about reproductive preferences, aiming at comparing them to real FHS data and question the validity of the indicators normally used. The main objective of this questionnaire was to capture the ideal number of children, that is, the ones that the couples wanted to have or had. On the other hand, during the interview the intentions for children were gathered from questions about the real will and viability of having this ideal number of children.

The recruitment of respondents was done by convenience and using the 'snowball' technique, in which participants suggest potential interviewees. Interviews were conducted by the first author, who followed a semi-structured interview guide, allowing for a more active dialogue among the interviewees and expansion of topics of interest for the research. The interviews took place in the location chosen by respondents (home, work, and public square) and lasted 45 minutes on average. They were recorded, transcribed and interpreted using content analysis.

Participants were given false names to guarantee confidentiality and are also identified by the number of children and age, so that the reader can make sure that the quotes used reflect opinions coming from different people and not the same ones. The quotes are always presented in italics and between quotation marks ("Tells the respondent"). The interviewer's questions are marked in brackets ([Myspeech]) and what appears sporadically in parentheses in the interviewee's identification of the end is additional information which helps the understanding of the context of that participant. Research procedures followed ethical principles governing research involving human subjects and was approved by the Ethics Committee of the University.

\section{Results and discussion}

The interviews offer the context of formation of desire for children as well as changes in plans, fertility behavior and consequences of these choices for individuals. At first, analysis was conducted based on a traditional indicator of fertility gap (number of desired children and children ever born). Table 1 indicates that the couples wanted an average of 2.2 children, with little difference between men and women. Although this is not a representative

\footnotetext{
1 The main question was: For women who had children: "If I could go back to the time when you had no children, and could choose the number of children to have for life, what number would this be?" For women without children: "If you could choose exactly how many children you would have in your life, how many would you have?"
} 
sample, this average corroborates the universality of two children as the ideal family size, also found in most developed countries as well as in Brazil (BONGAARTS, 2002; HAGEWEN; MORGAN, 2005; SOBOTKA; BEAUJOUAN, 2014; CARVALHO et al., 2016). It should be noted that there are clear differences in the ideal number of children according to the number of children already had (or not) by the couples. Those with no children desired an average of 1.6 children; among those with one child, the average ideal number of children was 2.1 ; and those who already had two children wanted 2.9 children and, in this case, women wanted more children than men. Among the 62 respondents, 50 claimed to have less children than desired. The highest prevalence of unrealized fertility was among couples with one child, again indicating the great rejection, at least theoretically, of the only child, followed by those couples who did not have children yet. It is interesting to note that the number of respondents with unrealized fertility was much smaller among couples with two children.

With regard to the perception of the number of children desired by the partner, it is observed (Table 1), that, irrespective of parity, couples believing that their partners want on average fewer children than were declared by them, was a trend most pronounced among couples with two children, where men believed that their partners on average wanted 2.6 children and they actually reported an average of 3.1. Likewise, the women in this group believed that their partners had an ideal of children around 2.6 and they reported an ideal of 2.8. Despite these differences, these data point to a very strong correlation between the data provided by the respondents and those provided by their partners, indicating that women's response to partners' wishes can be good predictors of the couple's behavior (THOMSON et al., 1990).

TABLE 1

Average ideal number of children and unrealized fertility $(n=62)$, according to wife's and husband's response about parity

Belo Horizonte - 2013

\begin{tabular}{|c|c|c|c|c|c|c|c|}
\hline \multirow[b]{2}{*}{ Answers } & \multicolumn{2}{|c|}{ Childless couple } & \multicolumn{2}{|c|}{ One child couple } & \multicolumn{2}{|c|}{ Two children couple } & \multirow{2}{*}{$\begin{array}{l}\text { General } \\
\text { average }\end{array}$} \\
\hline & $\begin{array}{c}\text { She } \\
\text { desires }\end{array}$ & $\begin{array}{c}\mathrm{He} \\
\text { desires }\end{array}$ & $\begin{array}{c}\text { She } \\
\text { desires }\end{array}$ & $\begin{array}{c}\mathrm{He} \\
\text { desires }\end{array}$ & $\begin{array}{c}\text { She } \\
\text { desires }\end{array}$ & $\begin{array}{c}\mathrm{He} \\
\text { desires }\end{array}$ & \\
\hline $\begin{array}{l}\text { In the women's questionnaire, } \\
\text { she said... }\end{array}$ & 1.58 & 1.42 & 1.82 & 2.36 & 3.11 & 2.56 & 2.17 \\
\hline $\begin{array}{l}\text { In the men's questionnaire, he } \\
\text { said... }\end{array}$ & 1.50 & 1.58 & 1.64 & 2.45 & 2.56 & 2.78 & 2.27 \\
\hline Overall average desired fertility & \multicolumn{2}{|c|}{1.58} & \multicolumn{2}{|c|}{2.14} & \multicolumn{2}{|c|}{2.94} & 2.22 \\
\hline $\begin{array}{l}\text { Number of respondents with } \\
\text { unrealized fertility }\end{array}$ & 10 & 9 & 8 & 11 & 7 & 5 & 50 \\
\hline Number of couples interviewed & \multicolumn{2}{|c|}{12} & \multicolumn{2}{|c|}{11} & \multicolumn{2}{|c|}{8} & 31 \\
\hline
\end{tabular}

Source: Data from the mini questionnaire applied to respondents.

Another issue regarding the DHS-type question is that, as was already pointed out by some critics of this indicator (GAUTHIER, 2007; GOLDSTEIN et al., 2003), this question proved rather confusing. For some respondents, it seemed more like a reflection on social norms about ideal family size than about their own individual preferences. As an example, 
when asked, some interviewees asked the interviewer if they should answer about the ideal of children they thought people should have or if they should answer about the ideal number they wanted to have themselves. Naturally, they were then instructed to report on their individual preferences. Thus, it is believed that other respondents may have had similar doubts before. Consequently, this indicator, given the way in which the question is traditionally asked, may not adequately reflect individual expectations about having children.

Questions were raised regarding the way interviewees idealized the number of children reported on average. The words below clearly show the formation of fertility desires and intentions are results of social experiences lived by the individuals, such as their number of siblings or financial conditions (AXIM et al., 1994; RÉGNIER-LOILIER, 2006; HAYFORD, 2009). These connections seem to act both in individuals having chosen to refute lived experiences as well as to reapply them.

"Since I was always raised within the family, a family of lunches and get-togethers, I think that in our family there had to be at least three" Lucas, 3 sons, 54 years-old

"I am the daughter in a family of four siblings, so we had hard times, everything was very tight, so I thought: 'When I get married, I'm going to have a son, but I'm only going to have only one, because then I can give him everything, I'm going to give all the incredible treats to eat, take him to all of the great places". (Carolina, 1 son, 35 years-old)

"Back at home, there are four brothers, so I always thought of at least four". (Ronaldo, 1 son, 35 years-old)

Among the couples interviewed, there was a clear preference for two children and a strong rejection of having an only child, with many participants using examples and negative questions about the experience of having an only child. The words below exemplify several justifications for having a second child: providing company for the first child, being able to "pamper" single children, having a child of each sex, application of the existing social norm of two children (SOBOTKA; BEAUJOUAN, 2014).

"I want this for [son], I want him to have a little brother to play with, so he can..." I don't want to have more than one son, I want my son to have a brother, like my brother was to $m e "$. (Augusto, 2 sons, 40 years-old)

"I joke with my husband that an only child is a trap, so, so you can fall into it or not. You have to pay attention, be very careful, psychologically prudent and everything so you won't fall into that trap, because the child turns into a little king or a little queen of the home." Ana Maria, 2 children, 39 years-old

"I always thought about that, a girl and a boy". (João, 2 children, 39 years-old)

"In truth, having one [child] I just think we never thought about that, just because of our personal stories. I told you I came from a family of seven and Lucia from a family of five. Before that, families as well as hers and mine were bigger, thus the question of an only child was never thought of by us". (Henrique, 2 children, 45 years-old)

The social networks of interviewees also showed a strong relation to the process of forming desires and intentions for children. In addition to caring for children properly, they judged the 
couple's choices and behavior. These social actors used schemes to determine how to act, to justify their actions and to evaluate the actions of others; which may interfere with the planning and reproductive behavior of couples (BALBO; MILLS, 2011; JOHNSON-HANKS et al., 2006). For couples without children, cohabitation networks seem to put great pressure on them to have children, not being sympathetic with the option of (still) having had no children. Couples who already had children were, at times, pressed to have a second child. That is, there are still constraints and it is not expected, even among more educated and higher-income couples, to postpone childbirth, choose not to have children or have few of them.

"There was no questioning, it was always something like that, as though it were an obligation, as though one thing was connected to the other: you have to get married, you have to have a child; the human being was meant to bear children. As though this was the only objective in life or some type of achievement". (Teresa, no children, 38 years-old) "I get this pressure. A lot of people: 'But aren't you going to have any? What a problem! How ridiculous. And what's going to happen when you grow old?', as though it were a synonym for "you should be cared for by your child". (Rafaela, no children, 39 years-old)

It is also important to note that the pressure and suggestions of social networks seem to follow a normative pattern of two children. If, on the one hand, having children is stimulated among those who do not any or only have one child, on the other hand, couples who want more than two children are also questioned. They reported that this possibility seems to be widely discouraged by close people, since having three or more children is almost considered as insanity. These findings corroborate other studies showing societies, increasingly, idealize two as the perfect number of children, especially because that number could adequately reconcile financial and emotional resources (SOBOTKA; BEAUJOAN, 2014).

"Other people, colleagues, the majority say: 'You are crazy! You are insane! Two is a good number.' This, then, this is very reactionary. I think the majority of people are scared when you say "I have three children". (Karine, 2 sons, 38 years-old)

"I think that this number two is interesting because it seems that people accept it well. It seems that with three, they begin to say it is a bit crazy, but two is an acceptable number". (Helena, 2 children, 38 years-old)

Respondents also reported the changes in these desires throughout their lives, since they formulate their intentions to behave in a way, but when confronted with real situations and choices, they have changed their behavior in the face of this new reality (BARBER, 2011). When they were young, they had a different number of children reported as desired, compared to the number they have today. In addition, they note that their desires have changed over time, and usually tend to be smaller over the years and with experience. Late marriage, financial issues, preferences between career and leisure, as well as lack of rationality regarding the implementation of reproductive intentions, were some of the reasons pointed out to explain why the ideal reproductive plans did not succeed. Nonetheless, individuals found alternative paths and adapted. 
"Time went by. We wanted to work, get a specialization, and when we decided to live together, I was already 35 years-old. And then we have that, as time goes by, the more you see the vision of getting married and having a child is a bit too romantic". (Cristina, no children, 38 years-old)

"It changed a lot. Personally, I was a bit indifferent before, I imagined it would be a very radical, serious transformation, one that I wouldn't be willing to face". (Pedro, no children, 43 years-old)

"Everything turned out to be the other way round. To begin with, at 25 I was not even dating, I was not married. I wanted to be a young mother and I became a mother after 35 years-old" (Wanda, 1 child, 37 years-old)

"When I got married, initially I did want... Now, everything is different. I wanted to get married, have three children, initially. Later, I got married and I saw that, financially, it was a very big expense, because there is a house, there are heaps to get done, then, I wanted two". (Lara, 1 child, 37 years-old)

Among men, especially among those who were not parents, the desire for children decreased with age and the reason is not very clear. The statements below indicate that often the ideal family size may not be a goal, but something that is found over time. Moreover, this measure becomes very imprecise, as it does not provide actual information on the intention to actually have those children (PHILIPOV et al., 2009).

"I think when I was younger, I had more of an intention to have children and maybe more children. As time goes by, I perceive this is decreasing, the wish to have a child and also the number is maybe decreasing". (Humberto, no children, 41 years-old)

"As time went by I stopped wanting to have a child, and it is hard to tell why". (Vitor, no children, 39 years-old)

These interview fragments refer to the previous discussion about the importance of considering the differences in the desire to have children over time, which may be positive at some point and become negative at another time. It is precisely the combination, and which of them will exert greater pressure for a longer time what will determine the outcome of fertility (MILLER et al., 2013, 2016).

Analyzing the fertility behavior itself, it is possible to verify in Table 1 that, on average, the majority of the individuals had a negative discrepant fertility. Among those without children, the desired average was 1.58 children, those who already had one child wanted to have 2.14 children and among those with two children, the desired fertility was 2.94 children. That is, they wanted to have more children than they actually had. Intuitively, one might think that these couples, even though they may still have children, would be dissatisfied with their current fertility and consequently, would be in a disadvantageous condition compared to those with exactly the number of desired children. However, these relationships are quite complex and cannot be simplified. Especially because, as discussed in previous sessions, this indicator has several methodological problems. Thus, it is important to observe and understand the extent to which this negative discrepancy of 
fertility translates into a dissatisfaction on the part of the individual with regard to their observed fertility behavior.

Childless couples appear to be the ones who would most likely approach the situation with actual dissatisfaction with their fertility behavior, since only two couples actually reported not wanting to have children. Most, on the contrary, said that they would like at least one. Curiously, there seems to be a great impasse, since the majority of couples who have no children and who have declared an ideal of two or three made it very clear during the interview that if they have children, they will have one child at the most. That is, despite the desire for two or more, this number is not real, since they know they will not reach this number, because the current intention to have children is much lower. This fact, then, masks the real dissatisfaction of these couples because, if dissatisfaction were calculated simply based on the measure of discrepancy, it would be much higher than it really is. There is always some fantasy in this type of response and people change and rethink the ideal number of children depending on the circumstances (GOLDSTEIN et al., 2003; PHILIPOV; BERNARDI, 2011).

"Now we know that we are only going to have one. Today, I do not feel like having two" (Marina, no children, 37 years-old. Declared that it would be ideal to have two, but intends to have one)

[What about those three that you said, do you think you are going to have them?] "I don't think so. Today I feel that 'If I have one, thank God, excellent"'. (Fernanda, no children, 37 years-old. Declared 3 children an ideal but intends to have one)

"Really I think there is going to be one. She talks a lot about one. I don"t know if there is going to be time to have another because it takes such a long time". (Alberto, no children, 33 years-old. Declared an ideal of two but he intends to have one)

"Well, I plan for the future and we are going to build a family, have about two children, because four, that number I talked about, is sort of an Alice in Wonderland number. Really, [I plan] about two children, continue doing what I like and age well, because when you get old, you need to worry about health". (Daniel, no children, 44 years-old. Declared the ideal would be 4 children but he wants to have two)

This disparity between the number of desired and realized children occurred among couples who had one and two children also. They declare a very high ideal number of children, but consciously revealed that this number would not materialize. In these cases, especially among couples with one child, the discrepancy does not seem to be related to dissatisfaction, since the second child seems to be much more a companion for the first child than to actually satisfy a desire for more children. The main reasons for not achieving the initial desired fertility was the high cost of raising children at the levels desired by them.

"If someone turns and says, If I could have, I do not know, If I won the lottery, I would now have three, but reasonably and financially I would have two". (Bruna, 1 child, 37 years-old. Declared an ideal of three children, but just wants to have the second child)

"Then, thus, due to all of that, I feel satisfied. If Lucas [husband] had the intention "I want one more [child]. Let us have one more', I think I would be able to change that. But today 
I think everything is ok, but I cannot have one more [child] to stop everything up again". (Marina, 1 child, 39 years-old. Declared an ideal of two children, but she does not want to have the second child)

"Now, the third one is what we are uncertain about. Due to education, we know it makes things tighter. After that second [child], we saw how much that increased our expenses. To have another one, we would have to move, because it is possible for four to live in the apartment, but five or even six, if twins come, since her [wife's] family has twins...". (Bernardo, 2 children, 46 years-old. Declared an ideal of 4 children; however, he still does not know whether he will have more children)

\section{Closing remarks}

The analysis of the traditional DHS-type reproductive indicators confirms the strong prevalence of negative fertility discrepancy among the 31 educated couples interviewed in Belo Horizonte. However, results from in-depth interviews, show that most of them were very satisfied with their current fertility situation. Thus, unrealized fertility does not always translate into dissatisfaction due to lack of children, as suggested by Peri and Pardo (2008). According to our research, an individual can claim to have less children that desired and still be satisfied with the number of children they have.

Dissatisfaction with fertility behavior was identified only among couples without children. Among those with children, but less than desired, the truth is there was very little dissatisfaction with fertility behavior. Most couples were not willing to implement their fertility desires and seemed to be satisfied with becoming a parent, which is derived from having a child rather than by reaching the ideal number of children. In addition, we believe that the norm of having children (versus being childless) may help increase the discrepancy between the higher desired number of children and the lower actual number of children.

The number of children declared as desired by most interviewees was not meant to be transformed into reality because they rely on family size experiences that they had as children, as well as the social context in which they were raised (AXINN et al., 1994; RÉGNIERLOILIER, 2006; HAYFORD, 2009). Therefore, the ideal number of children declared in the present time is influenced by subjective norms based on past fertility patterns, from a time when the number of children was much higher and, consequently, the number of siblings. These wishes refer to other moments in time (when they were younger, when they had not become mothers and fathers yet), which respond to social norms and the expected behavior imposed by them. Even among this highly educated group, considered avant-garde for the so-called second demographic transition, there seems to be a continuation of past fertility preferences, indicating a certain 'inertia of norms' with regard to reproductive preferences.

The interaction of family social networks may operate as a multiplier of individual and social factors which have driven the trend towards low fertility in Europe (KOHLER et al., 2002). In the Brazilian case, as also noted in the study for Germany (KOTTE; LUDWIG, 2011), this interaction seems to lead to a transfer of higher reproductive preferences 
between generations, since desires were derived of the family-size and family experience that respondents had.

However, the same does not apply to intentions and actual fertility behavior. Actual fertility behavior is influenced by changes and events that occur throughout the individual's life, as well as current economic, political, and social circumstances. Thus, one of the issues about comparing desired and actual number of children is the time-lag between these indicators. In addition, family size preferences may change during the course of the individual's life.

Despite these and possibly other measurement problems, unrealized fertility is a growing phenomenon in Brazil since a significant reduction in fertility in the coming decades is expected and, consequently, an increasing gap between desired and realized fertility may follow. Negative discrepancy can become a social problem requiring effective public policies, and further studies to understand the ways in which individuals deal with this phenomenon are required.

The above urges to think about the currently available indicators used in research in the country, particularly in view of the possibility of carrying a National Health Survey of Women and Children. The number of DHS-type questions available is very limited, controversial and inefficient, as demonstrated above. We recommend a review and update of questions on reproductive preferences and fertility planning, based on questions that have already been tested in other countries, as well as on the lessons learned from our qualitative data. As a suggestion, it is important to reinforce the question about ideal number of children, clarifying that this number refers to personal desire and not to social ideal, as well as make it clear that not having children is also a possible answer for this question. It would also be interesting to have this question at two moments in life, when respondents were young and at the time of interview. Understanding what induces the formation of the ideal number of children and the intention of having them in a shorter period would also be very useful. Another relevant piece of information is the reasons leading to postponement and unrealized fertility. Since normally available date are not capable of measuring the actual satisfaction with the number of children, it is necessary to have information about the individuals' satisfaction with their fertility behavior and consequences of the unrealized fertility for the couple and the individual's life.

Finally, we suggest the expansion of research on fertility gap and satisfaction and make three recommendations. First, qualitative data are always welcome, albeit not representative. The friendly and relaxing environment during interviews certainly did make the conversation about fertility preferences flow more easily, as found by Yeatman et al. (2013). Second, on the quantitative side, asking men the same questions would provide complementary information and help to understand how couples plan their children. Finally, longitudinal studies would allow for the actual measurement of unrealized fertility and the understanding of the limiting mechanisms operating in this process. All this information will contribute to the design of public policies that guarantee reproductive rights. 


\section{References}

ADSERA, A. An economic analysis of the gap between desired and actual fertility: the case of Spain. Review of the Economics of the Household, v.4, p. 75-95, 2006.

ARPINO, B.; ESPING-ANDERSEN, G.; PESSIN, L. How do changes in gender role attitudes towards female employment influence fertility? A macro-level analysis. European Sociological Review, v. 31, n. 3, p. 370-382, 2015.

AXINN, W. G.; MARIN, E. C.; THORNTON, A. Family influences on family size preferences. Demography, v. 31, n. 1, p. 65-79, 1994.

BACHRACH, C. A.; MORGAN, S. P. A cognitive-social model of fertility intentions. Population and Development Review, v. 39, n.3, p. 459-485, 2013.

BALBO, N.; MILLS, M. The influence of the family network on the realization of fertility intentions. Vienna Yearbook of Population Research, v. 9, p. 179-206, 2011.

BARBER, J.S. The theory of planned behavior: considering drives, proximity and dynamics. Vienna Yearbook of Population Research, v.9, p. 31-35, 2011.

BELLANI, D.; ESPING-ANDERSEN, C. Education, employment, and fertility. In: ESPING-ANDERSEN, G. (Ed.). The fertility gap in Europe: singularities of the Spanish case. "la Caixa” Welfare Projects, 2013.

BERQUÓ, E.; LIMA, L. P. de. Intenções reprodutivas e planejamento da fecundidade. Relatório Final da Pesquisa Nacional de Demografia e Saúde da Criança e da Mulher 2006. Brasília: Ministério da Saúde, 2008.

BERRINGTON, A.; PATTARO, S. Educational differences in fertility desires, intentions and behaviour: a life course perspective. Advances in Life Course Research, v. 21, p. 10-27, 2014.

BONGAARTS, J. Do reproductive intentions matter? International Family Planning Perspectives, v. 18, n. 3, p. 102-108, Sep. 1992.

. Fertility and reproductive preferences in post-transitional societies. Population and Development Review, v. 27, p. 260-281, 2001.

. The end of the fertility transition in the developed world. Population and Development Review, v. 28, p. 419-443, 2002.

. Can family planning programs reduce high desired family size in Sub-Saharan Africa? International Perspectives on Sexual and Reproductive Health, v. 37, n. 4, p. 209-216, 2011.

CALDWELL, J. C.; REDDY, P.; CALDWELL, P. The social component of mortality decline: an investigation in South India employing alternative methodologies. Population Studies, v. 37, n. 2, p. 185-205, Jul. 1985.

CARVALHO, A. A.; WONG, L. L. R.; MIRANDA-RIBEIRO, P. Discrepant fertility in Brazil: an analysis of women who have fewer children than desired (1996 and 2006). Revista Latinoamericana de Población, n. 18, p. 83-106, 2016.

CASTERLINE, J. B.; EL-SEINI, L. The estimation of unwanted fertility. Demography, v. 44, n. 4, p. 729-745, Nov. 2007.

CASTERLINE, J. B.; HAN, S. Unrealized fertility: fertility desires at the end of the reproductive career. Demographic Research, v. 36, n. 14, p 427-454, 2017.

CHACKIEL, J.; SCHKOLNIK, S. América Latina: los sectores rezagados en la transición de la fecundidad. In: CELADE/CEPAL (Org.). La fecundidad en América Latina: ¿Transición o revolución? Santiago de Chile: Celade/Cepal, 2003. p. 51-74. 
CHESNAIS, J. C. Determinants of below replacement fertility. Population Bulletin of the United Nations, n. 40/41, p. 126-136, 1999.

CREIGHTON, M.; ESPING-ANDERSEN, G.; RUTIGLIANO, R.; VAN DAMME, M. Is fertility influenced by couple instability? In: ESPING-ANDERSEN, G. (Ed.). The fertility gap in Europe: Singularities of the Spanish case. "la Caixa” Welfare Projects, 2013.

DEMENY, P. Replacement-level fertility: the implausible endpoint of the demographic transition. In: JONES, G. W.; DOUGLAS, R. M.; CALDWELL, J. C.; D’SOUZA, R. M. (Ed.). The continuing demographic transition. Oxford: Clarendon Press, 1997.

GAUTHIER, A. H. The impact of family policies on fertility in industrialized countries: a review of the literature. Population Research and Policy Review, v. 26, n. 3, p. 323-346, 2007.

GOLDSTEIN, J. R.; LUTZ, W.; TESTA, M. R. The emergence of sub-replacement family size ideals in Europe. Population Research an Policy Review, v. 2, n. 2, p. 479-496, 2003.

GONZÁLEZ, M. E. D. A discrepância entre a fecundidade desejada e a fecundidade concretizada enquanto uma questão de gênero. Dissertação (Mestrado) - Universidade Estadual de Campinas (Unicamp), Campinas, 2015.

HAGEWEN, K. J.; MORGAN, S. P. Intended and ideal family size in the United States, 1970-2002. Population and Development Review, v. 31, p. 507-527, 2005.

HAKIM, C. A new approach to explaining fertility patterns: preference theory. Population and Development Review, v. 29, p. 349-374, 2003.

HAKKERT, R. Fecundidad deseada y no deseada en América Latina, con particular referencia a algunos aspectos de género. In: CELADE/CEPAL (Org.). La fecundidad en América Latina: ¿Transición o revolución? Santiago de Chile: Celade/Cepal, 2003. p. 267-288.

HAYFORD, S. R. The evolution of fertility expectations over the life course. Demography, v. 46, n. 4, p. 765-783, 2009.

IACOVOU, M.; TAVARES, L. P. Yearning, learning, and conceding: reasons men and women change their childbearing intentions. Population and Development Review, v. 37, n. 1, p. 89-123, 2011.

IBGE - Instituto Brasileiro de Geografia e Estatística. Projeções populacionais. Revisão 2013. Disponivel em: 〈https://ww2.ibge.gov.br/home/estatistica/populacao/projecao_da_ populacao/2013〉. Acesso em: 21 maio 2017.

JOHNSON-HANKS, J.; MORGAN; S. P.; BACHRACH, C.; KOHLER, H. P. The American family in a theory of conjunctural action. Berkeley, CA: Department of Demography, University of CaliforniaBerkeley, 2006 (Working paper).

KOTTE, M.; LUDWIG, V. Intergenerational transmission of fertility intentions and behaviour in Germany: the role of contagion. Vienna Yearbook of Population Research, v. 9, p. 207-226, 2011.

KOHLER, H. P.; BILLARI, F. C.; ORTEGA, J. A. The emergence of lowest-low fertility in Europe during the 1990s. Population and Development Review, v. 28, p. 641-680, 2002.

KUHNT, A. K.; TRAPPE, H. Easier said than done: childbearing intentions and their realization in a short-term perspective. Rostock, Germany: Max Planck Institute for Demographic Research, 2013 (Working paper, n. 2013/018).

LIEFBROER, A. C. Changes in family size intentions across young adulthood: a life-course perspective. European Journal of Population, v. 25, n. 4, p. 363-386, 2009.

MCCLELLAND, K. G. H. Family-size desires as measures of demand. In: BULATAO, R. A.; LEE, R. D. (Ed.). Determinants of fertility in developing countries. Supply and demand for children. New York: New York Academic Press, 1983. v. 1, p. 288-343. 
MCDONALD, P. Gender equity in theories of fertility transition. Population and Development Review, v. 6, n. 3, p. 427-439, 2000.

MILLER, W. B.; PASTA, D. J. Behavioral intentions: which ones predict fertility behavior in married couples? Journal of Applied Social Psychology, v. 25, p.530-555, 1995.

MILLER, W.B.; BARBER., J. A.; GATNY, H. H. The effects of ambivalent fertility desires on pregnancy risk in young women in the USA. Population Studies, v. 67, n. 1, p. 25-38, 2013.

MILLER, W. B.; JONES, J.; PASTA, D. J. An implicit ambivalence-indifference dimension of childbearing desires in the National Survey of Family Growth. Demographic Research, v. 34 , p. 203, 2016.

MORGAN, S. P. Intention and uncertainty at later stages of childbearing: The United States 1965 and 1970. Demography, v. 18, n. 3, p. 267-285, 1981.

MORGAN, S. P. Individual and couple intentions for more children. Demography, v. 22, p. 125 132, 1985.

MORGAN, S. P.; TAYLOR, M. G. Low fertility at the turn of the twenty-first century. Annual Review of Sociology, v. 32, p. 375-99, 2006.

MORGAN, S. P.; RACKIN, H. The correspondence between fertility intentions and behavior in the United States. Population and Development Review, v. 36, n. 1, p. 91-118, Mar. 2010.

NÍ BHROLCHÁIN, M.; BEAUJOUAN, E. How real are reproductive goals? Uncertainty and the construction of fertility preferences. ESRC Centre for Population Change, Dec. 2015 (Working paper, 73).

OECD. Babies and bosses. Reconciling work and family life. Paris: OECD Publishing, 2007.

PERI, A.; PARDO, I. Nueva evidencia sobre la hipótesis de la doble insatisfacción en Uruguay: ¿cuán lejos estamos de que toda la fecundidad sea deseada? In: WONG, L. R. (Org.). Población y salud sexual y reproductiva en América Latina. Rio de Janeiro: Alap, 2008. p. 55-88 (Serie Investigaciones, n. 4).

PHILIPOV, D.; THÉVENON, O.; KLOBAS, J.; BERNARDI, L.; LIEFBROER, A. C. Reproductive decisionmaking in a macro-micro perspective (REPRO): a state of the art review. European Commission within the Seventh Framework Programme under the Socio-economic Sciences and Humanities Theme, 2009 (Working paper).

PHILIPOV, D. Fertility intentions and outcomes: the role of policies to close the gap. European Journal of Population, v. 25, n. 4, p. 355, 2009.

PHILIPOV, D.; BERNARDI, L. Reproductive decisions: concepts and measurement in Austria, Germany and Switzerland. Comparative Population Studies, v. 36, n. 2-3, p. 495-530, 2011.

RÉGNIER-LOILIER, A. Influence of own sib ship size on the number of children desired at various times of life: The case of France. Population (english edition), v. 61, n. 3, p. 165-194, 2006.

RIJKEN, A.; LIEFBROER, A. The effects of relationship quality on fertility. European Journal of Population, v. 25, p. 27-44, 2009.

SANTELLI, J. S.; LINDBERG, L. D.; ORR, M. G.; FINER, L. B.; SPEIZER, I. Toward a multidimensional measure of pregnancy intentions: evidence from the United States. Studies in Family Planning, v. 40 n. 2, p. 87-100, 2009.

SOBOTKA, T.; BEAUJOUAN, E. Two is best? The persistence of a two-child family ideal in Europe. Vienna Institute of Demography, 2014 (Working papers, 3).

THÉVENON, O.; LUCI-GREULICH, A. The impact of family policy packages on fertility trends in developed countries. European Journal of Population, v. 29, n. 4, p. 387-416, 2013. 
THOMSON, E. Two into one: modeling couple behaviour. In: DIEGO, A. C. (Ed.). Family variables. Newbury Park, CA: Sage, 1990. p. 129-142. 1997. . Couple childbearing desires, intentions, and births. Demography, v. 34, p. 343-354,

WESTOFF, C. F.; RYDER, N. B. The predictive validity of reproductive intentions. Demography, v. 14, n. 4, p. 431-53, 1977.

. Reproductive intentions and fertility rates. International Family Planning Perspectives, v. 16, n. 3, p. 84-96, 1990.

WONG. L. L. R. Evidences of further decline of fertility in Latina America: reproductive behavior and some thoughts on the consequences on the age structure. In: CAVENAGHI, S. M. (Org.). Demographic transformations and inequalities in Latin America: historical trends and recent patterns. Rio de Janeiro: Alap, 2009 (Serie Investigaciones, n. 8).

YEATMAN, S.; SENNOTT, C.; CULPEPPER, S. Young women's dynamic family size preferences in the context of transitioning fertility. Demography, v. 50, n. 5, p. 1715-1737, 2013.

YIN, R. K. Case study research: design and methods. Sage Publications, cap. 4, 1994.

\section{About the authors}

Angelita Alves de Carvalho is $\mathrm{PhD}$ in Demography in Universidade Federal de Minas Gerais (UFMG). Professor and researcher in Escola Nacional de Ciências Estatísticas (Ence), Instituto Brasileiro de Geografia e Estatística (IBGE).

Laura Rodriguez Wong is PhD in London School of Hygiene and Tropical Medicine, Reino Unido. Professor in Centro de Desenvolvimento e Planejamento Regional (Cedeplar), Universidade Federal de Minas Gerais (UFMG).

Paula Miranda-Ribeiro is PhD in Sociology and Demography in University of Texas, Austin, USA. Professor in Centro de Desenvolvimento e Planejamento Regional (Cedeplar), Universidade Federal de Minas Gerais (UFMG).

\section{Contact address}

Angelita Alves de Carvalho

Escola Nacional de Ciências Estatíticas

Rua André Cavalcanti, 106, sala 503C, Bairro de Fátima

20231-050 - Rio de Janeiro-RJ, Brazil

Laura Rodriguez Wong

Cedeplar - Centro de Desenvolvimento e Planejamento Regional da UFMG, Faculdade de Ciências Econômicas

Avenida Presidente Antônio Carlos, 6627, $3^{\circ}$ andar, Pampulha

31270-901 - Belo Horizonte-MG, Brazil

Paula Miranda-Ribeiro

Cedeplar - Centro de Desenvolvimento e Planejamento Regional da UFMG, Faculdade de Ciências Econômicas

Avenida Presidente Antônio Carlos, 6627, $3^{\circ}$ andar, Pampulha

31270-901 - Belo Horizonte-MG, Brazil 


\section{Resumo}

Alice no País das Maravilhas: fecundidade não realizada e satisfação com o número de filhos tidos de acordo com o ponto de vista dos casais em uma cidade do Brasil

No Brasil, o hiato entre fecundidade ideal e observada é cada vez mais comum. Paralelamente, perante as severas críticas feitas aos indicadores disponíveis sobre o tamanho desejado/ideal de família, torna-se relevante refletir sobre até que ponto as respostas das pessoas refletem adequadamente suas preferências. 0 objetivo deste artigo é discutir se ter menos filhos do que o desejado é fruto de uma escolha ou se representa, de fato, uma incapacidade de implementação das preferências reprodutivas e uma insatisfação com o seu comportamento de fecundidade. Utilizam-se dados de 62 entrevistas em profundidade realizadas com $31 \mathrm{com}$ casais de alta escolaridade com até dois filhos, residentes em Belo Horizonte, Brasil. Pode-se verificar que a fecundidade discrepante negativa predominou para a maioria dos casais entrevistados. Nota-se, porém, que uma parte importante destes casais está totalmente satisfeita com a situação atual de fecundidade, já que não pareciam dispostos a efetivar o desejo de aumentar o número de filhos.

Palavras-chave: Hiato de fecundidade. Fecundidade discrepante negativa. Medidas de preferência de fecundidade. Dados qualitativos. Casais.

\section{Resumen}

Alicia en el País de las Maravillas: fecundidad no realizada y satisfacción con el número de hijos tenidos de acuerdo con el punto de vista de las parejas en una ciudad de Brasil

La brecha entre ideales de fecundidad y fecundidad observada es cada vez más común en Brasil. Complementariamente, ante las severas críticas a los indicadores disponibles sobre el tamaño deseado e ideal de familia, es importante reflexionar hasta qué punto las respuestas de las personas reflejan adecuadamente sus preferencias reproductivas. El objetivo de este artículo es discutir si tener menos hijos de los deseados se configura como opción o si, de hecho, representa una incapacidad de implementación de las preferencias reproductivas y un descontento con su comportamiento de fecundidad. Se utilizarán datos de entrevistas en profundidad hechas a 31 parejas con alta escolarización, residentes en Belo Horizonte, Brasil, con hasta dos hijos. Si bien se observa que la fecundidad discrepante negativa predomina en la mayoría de las parejas entrevistadas, también se observa que, dentro de esta mayoría, existe una proporción importante totalmente satisfecha con esta situación, que no parecía estar dispuesta a aumentar su número de hijos.

Palabras clave: Brecha de fecundidad. Fecundidad discrepante negativa. Medidas de preferencia de fecundidad. Análisis cualitativo. Parejas. 